\title{
In Vitro Cytotoxicity Test Reveals Non-toxic of Waste-based Scaffold on Human Hepatocyte Cells
}

\author{
Oktantia Frenny Anggani ${ }^{1 *}$, Aniek Setiya Budiatin ${ }^{2}$, Laksmi Sulmartiwi ${ }^{3}$ and \\ Muhammad Rahmad Royan ${ }^{4}$ \\ ${ }^{1}$ Biotechnology Fisheries and Marine, Faculty of Fisheries and Marine, Airlangga University, $\mathrm{Jl}$. \\ Mulyorejo, Mulyorejo, Surabaya 60115, Indonesia \\ ${ }^{2}$ Department of Clinical Pharmacy, Faculty of Pharmacy, Airlangga University, Jl. Mulyorejo, \\ Mulyorejo, Surabaya 60115, Indonesia \\ ${ }^{3}$ Department of Marine, Faculty of Fisheries and Marine, Airlangga University, Jl. Mulyorejo, \\ Mulyorejo, Surabaya 60115, Indonesia \\ ${ }^{4}$ Physiology Unit, Faculty of Veterinary Medicine, Norges Miljø- og Biovitenskapelige Universitet, \\ Campus Adamstuen, 0454 Oslo, Norway
}

*Correspondence :

ayuoktantia@gmail.com

Received : 2020-10-25

Accepted : 2020-12-07

Keywords :

Crab chitosan, Bovine gelatin, Chondroitin sulfate, Cytotoxicity

\begin{abstract}
Scaffold, as one of the components for bone tissue engineering, requires formulated biomaterials that are both structurally and compositely similar to bone composition. Among others, chitosan, gelatin, and chondroitin sulfate are known as potential candidates for scaffold composites that can be easily obtained from waste-based resources. This study aims to investigate the cytotoxicity of different scaffold composition and concentration regimes derived from wastebased chitosan, gelatin and chondroitin sulfate, in vitro. The composition regimes used were (Chitosan : Gelatin : Chondroitin Sulfate) $50: 50: 0$ (A); $50: 40: 10$ (B); $50: 35$ : 15 (C); $50: 30: 20$ (D); $50: 25: 25$ (E). Meanwhile, the final concentrations of scaffold used were 2000, 1000, 500, 250, 100,10 and $0,1 \mathrm{mg} / \mathrm{ml}$. The different compositions and concentrations of the scaffold were tested against Hepatocellular Carcinoma (Huh7it/Human Hepatocyte It). After 48-hour incubation in the scaffold solution, the percentage of cell viability was evaluated using 3-(4,5dimethylthiazol-2yl)-5(3-carboxymethoxyphenyl)-2-(4-sulfophenyl)-2H-tetrazolium (MTT) assay. The result shows that there is no difference observed among different scaffold compositions on cell viability ( $p>0.05$ ). However, different concentrations of scaffold show significant differences in cell viability in composition $\mathrm{C}$ and $\mathrm{E}(\mathrm{p}<0.01)$, suggesting a possible dose-dependent effect of scaffold on cell viability. Overall, all the waste-based scaffold compositions show no toxicity against the Hepatocellular Carcinoma cells as exhibited by the cell viability that is above $70 \%$, at least with the concentration up to $2000 \mathrm{mg} / \mathrm{ml}$.
\end{abstract}

\section{INTRODUCTION}

A scaffold is a component of bone tissue engineering that can be used to repair damaged bone tissue (Venkatesan et al., 2015). A scaffold must have good 
mechanical properties to maintain the balance of its biological function, as well as have high porosity, good bioactivity and biodegradability (Kartikasari et al., 2016). A previous study shows that scaffolds with good physical, chemical and mechanical properties can transmit growth factors to the cells, and these factors are used as biochemical signals that indicate tissue growth (O'Brein, 2011). It has been acknowledged that scaffold derived from natural polymer materials enhances its physical, chemical and mechanical properties.

Considering some disadvantages from previous composites in scaffold production, the use of the natural polymer materials as scaffold biomaterial composites needs to be developed because natural polymeric material has several advantages, such as longer storage period, cost-effective, flexibility in terms of shape formation, better cell differentiation properties, porous characteristics and high mechanical strength (Gunatillake et al., 2006). One of the natural polymer materials that can be used is chitosan. Mostly composed in crab shells, chitosan has been shown to be one of the potential scaffold composites (Levengood and Zhang, 2014). As a naturally occurring polymer, chitosan has a porous scaffold formation with interconnected pores and has been shown to increase bone formation both in vitro and in vivo (Escobar-Sierra et al., 2015). However, chitosan is considered to be easily degraded (Hartatik et al., 2014), so some additional biomaterials are required to improve its physical, biological and mechanical properties.

Gelatin is one of the additional compounds that can be used to increase chitosan quality as the scaffold material. Gelatin is a natural product obtained from partial hydrolysis of collagen from animal skin and bones (Duconseille et al., 2015). Gelatin originated from mammals is more widely used due to its high melting tint, good gelling agent, thermoreversible (Puspitaningrum, 2015), and its use as a composite adhesive (Juliasti et al., 2014).
However, gelatin easily loses its form and size properties (Peng et al., 2006) and has low mechanical strength. Thus, it should be supported by other materials capable of enhancing its mechanical strength.

Chondroitin sulfate is considered as the candidate material that can be used to increase the mechanical strength of the composite (Neves et al., 2020). Indeed, chondroitin sulfate has been shown to stop cartilage degradation and restore cartilage losses due to its biochemical feature (Singh et al., 2015). Chondroitin sulfate is one of the five classes of glycosaminoglycans required for the formation of proteoglycans present in cartilage (Siagan, 2014). Moreover, Chondroitin sulfate has a hydrophilic structure, a gelling polysaccharide macromolecule that can facilitate the joints prone to absorb a large amount of water, thus making the joints act as a cushion to absorb the compression force that occurs (Kavya et al., 2012; Siagan, 2014). The use of chondroitin sulfate is suggested to increase scaffold porosity, low biodegradation and does not cause cytotoxicity (Wijayanti, 2016).

Those aforementioned scaffold composites are known as potential biomaterials to produce high-quality scaffold. Interestingly, those composites can be obtained from waste products. For instance, shell waste from crab products can be used as the source of chitosan. Gelatin can also be obtained from animal by-products, such as cow bone waste, while chondroitin can also be extracted from cow cartilage waste. The production of scaffold biomaterials using waste-based composites will both increase the added value of waste products and reduce the scaffold production cost, which in turn offers many advantages to tissue engineering and regenerative medicine research.

Since only a few studies investigate the optimal composition that can be used in scaffold formulation using the abovementioned composites, further research is needed to determine the optimal chitosangelatin-chondroitin sulfate scaffold 
compositions. This study aims to investigate the cytotoxicity of different compositions of crab shell chitosan, bovine gelatin and chondroitin sulfate against Hepatocellular

Carcinoma (Huh7it/Human Hepatocyte It) cells, and the outcome will benefit the research community in developing the optimal and cost-effective scaffold for tissue engineering and regenerative medicine research.

\section{METHODOLOGY}

\section{Place and Time}

This research was conducted at the Tropical Disease Diagnostic Center (TDC), Airlangga University, Surabaya on 15-29 February 2020.

\section{Research Material}

The tools used in this research were Erlenmeyer flask, petri dish, $2 \mathrm{ml}$, plastic cotton bottle, cotton ball, measuring cup, measuring pipette, aluminum foil, hotplate stirrer, microcentrifuge tube, 96microwell plate, freeze dryer, analytical scale, spatula, ultrasonic sonicator bath, ELISA reader glomax microplate multidetection reader (Promega).

The materials used in this research were commercial powder of crab chitosan (Semarang, Indonesia), bovine gelatin (Indonesia) and chondroitin sulfate (Faithful Xian, China), glacial acetic acid (Merck), aquadest (Air Liquide, Indonesia), MTT solution (SigmaAldrich), media eagle's (Invitrogen Carlsbad, CA, USA), 10\% fetal bovine serum (Biowest, Nuaille, France), kanamycin (Sigma Aldrich, St. Louis, MO, USA), non-essential amino acids (Invitrogen), DMSO (Merck), Hepatocellular Carcinoma cell (Huh7it/Human Hepatocyte It).

\section{Research Design}

The study was conducted using completely randomized design with five composition groups. Percent compositions used in this study were (Chitosan : Gelatin : Chondroitin Sulfate) $50: 50: 0$ (A); 50 :
$40: 10$ (B); $50: 35: 15$ (C); $50: 30: 20$

(D); $50: 25: 25$ (E).

\section{Work Procedures}

\section{Preparation of Chitosan-Gelatin- Chondroitin Sulfate Scaffold Composites}

Acetic acid solution (2\% in distilled water) was used to dilute the chitosan powder as previously described in (Venkatesan et al., 2015) by homogenizing the mixture for 5 hours at RT. Gelatin (diluted in distilled water) was made at $40{ }^{\circ} \mathrm{C}$ and then mixed with the chitosan solution according to the composition regimes (A-E). Chondroitin sulfate is added gradually into the chitosan and gelatin mixture according to composition regimes. The chitosangelatin-chondroitin sulfate mixture was stored at $-18{ }^{\circ} \mathrm{C}$ for 24 hours and subsequently frozen in a $-40{ }^{\circ} \mathrm{C}$ freeze dryer for 48 hours by isolating all sides. Finally, the formed scaffold was crushed and $1 \%$ of the scaffold diluted in $1 \mathrm{X}$ Phosphate Buffer Saline (PBS) was later incubated in an ultrasonic sonicator bath at $30^{\circ} \mathrm{C}$ for 5 minutes before proceeded to the cytotoxicity assay.

\section{Huh7it Cell Culture}

Huh7it hepatocytes were cultured in Dulbecco's modified Eagle medium with the addition of $10 \%$ fetal bovine serum, $150 \mathrm{mg} / \mathrm{ml}$ kanamycin and non-essential amino acids. When cell growth in the petri dish reached more than $80 \%$, a passage cell was performed. Cells were incubated for 24 hours and later transferred into a 96-microwell plate. After obtaining the density of $2.4 \times 10^{4}, 100 \mathrm{ml}$ of scaffold solution was added into each well and incubated again for 48 hours at $37{ }^{\circ} \mathrm{C}$ before the cytotoxicity test.

\section{Cytotoxicity Test}

To evaluate the toxicity of scaffold solution against the cultured cells, the toxicity test was performed using the MTT [3-(4,5-dimethylthiazol-2yl)-5(3-carboxymethoxyphenyl)-2-(4-sulfophenyl)-2H- 
tetrazolium] assay. Scaffold solution in the cell wells was discarded, and the cells were then incubated with $150 \mathrm{ul}$ of $10 \mathrm{X}$ MTT solution for 4 hours. Afterward, 100 ul of dimethyl sulfoxide (DMSO) was added to dissolve the precipitate formed from the MTT reaction. The final concentrations of the scaffold used in this assay were $2000 \mathrm{mg} / \mathrm{ml}, 1000 \mathrm{mg} / \mathrm{ml}, 500$ $\mathrm{mg} / \mathrm{ml}, 250 \mathrm{mg} / \mathrm{ml}, 100 \mathrm{mg} / \mathrm{ml}, 10$ $\mathrm{mg} / \mathrm{ml}$ and $0,1 \mathrm{mg} / \mathrm{ml}$. The absorbance was measured at $560 \mathrm{~nm}$ and $750 \mathrm{~nm}$ using the Glomax Microplate Multidetection Reader (Promega). The absorbance obtained was used to calculate the number of viable cells by the following formula (Cahyani, 2019) :

VC (\%)

$=\frac{\text { (abs. of treatment }- \text { abs. of control) }}{\text { (abs. of control cells }- \text { abs. of media controls) }}$ Note:
VC = Viability cells

Abs. $=$ Absorbance

\section{Data Analysis}

The data were analyzed using $\mathrm{R}$ Software System (v.3.50; The R Foundation for Statistical Computing, Vienna, Austria) with the level of significance 0.05. One-way ANOVA followed by Tukey post hoc test was used to evaluate the effect of different scaffold composition or different scaffold concentrations on the cell viability. The data in the graph is provided as mean \pm SD unless otherwise stated.

\section{RESULTS AND DISCUSSION Scaffold Products}

Scaffold products originated from different compositions (A-E) of chitosangelatin-chondroitin sulfate is shown in Figure 1.

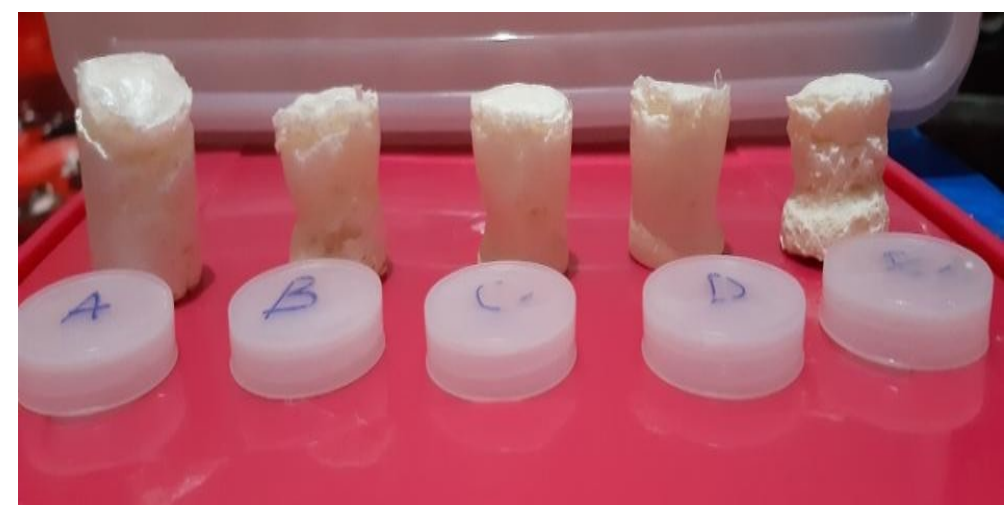

Figure 1. The scaffold products from different compositions of chitosan-gelatinchondroitin sulfate.

\section{Cytotoxicity Test}

Figure 2 illustrates the visual appearance of the plate from the cytotoxicity test against Hepatocellular Carcinoma (Huh7it/Human Hepatocyte It) cells after incubated with different compositions and concentrations of scaffold. As shown by Figure 2, all the test wells exhibit purple color as the positive control wells. This indicates that most of the cells are viable, and the result implied that different compositions and concentrations of scaffolds are not toxic to the cells. Indeed, living cells will react with MTT to form purple formazan, while the dead cell will not show any color. 


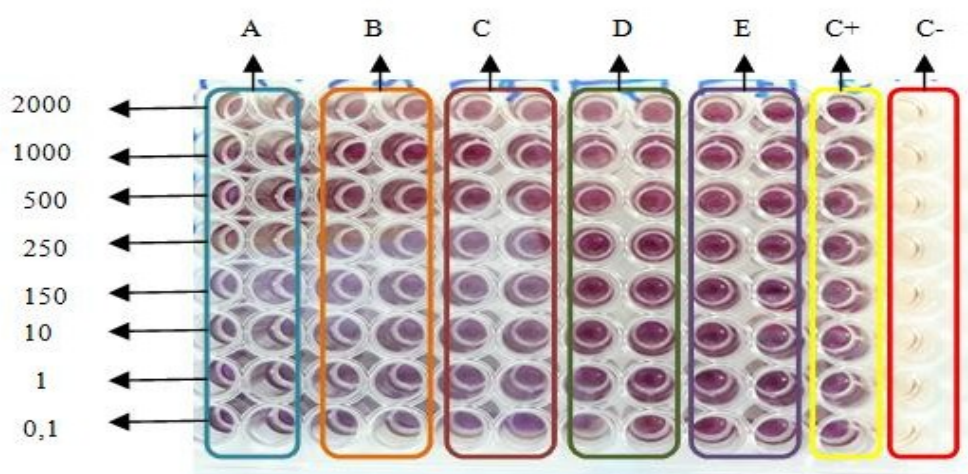

Figure 2. The visual appearance of the plate from cytotoxicity test against Hepatocellular Carcinoma (Huh7it/Human Hepatocyte It) cells after 48-hour incubation in different scaffold compositions and concentrations. (A) Composition A (50:50:0) + Huh7it cells (B) Composition B (50:40:10) + Huh7it cells, (C) Composition C (50:35:15) + Huh7it cells, (D) Composition (50:30:20) + Huh7it cells,(E) Composition E (50:25:25) + Huh7it cells, $(\mathrm{C}+$ ) Positive control (DMEM), (C-) Negative control (MTT). Black arrows point to the rows subjected to specific scaffold concentration $(\mathrm{mg} / \mathrm{ml})$.

Figure 3 shows the percentage of cell viability after incubated with different compositions and concentrations of the scaffold. According to the statistical analysis, there is no significant difference observed among different compositions of the scaffold ( $\mathrm{p}>$ 0.05). However, different concentrations of scaffold show differences in some scaffold compositions ( $p<0.01$ ). In composition $\mathrm{C}$, it is shown that cells incubated with $1 \mathrm{mg} / \mathrm{ml}$ and 0.1 $\mathrm{mg} / \mathrm{ml}$ scaffold have significantly higher viability than those incubated with 2000 $\mathrm{mg} / \mathrm{ml}$ scaffold $(\mathrm{p}<0.05)$. In addition, cells incubated in $0.1 \mathrm{mg} / \mathrm{ml}$ scaffold have significantly higher viability than those incubated in $1000 \mathrm{mg} / \mathrm{ml}$ scaffold. Meanwhile, in composition E, cell viability in $250 \mathrm{mg} / \mathrm{ml}$ treated cells is significantly lower than those in 100, 1 and $0.1 \mathrm{mg} / \mathrm{ml}$ treated cells. Despite not having significant differences in cell viability, the rest of the group still shows relatively higher cell viability. According to Nurfuadi (2019), scaffold composition showing more than $70 \%$ of cell viability indicates that it is not toxic to the cells. Therefore, the result indicates that every scaffold composition will not toxic to the cells at least up to $2000 \mathrm{mg} / \mathrm{ml}$.

In the cytotoxicity test carried out using tetrazolium salt (MTT), the yellow color in the salt will be reduced by the reductase system in the cell to form purple formazan crystals that are not dissolved in water. This happens because when metabolized, living cells will produce succinic dehydrogenase from the mitochondria (Nurfuadi, 2019). The intensity of purple color is positively correlated to the number of living cells, meaning the more the intensity, the higher the number of viable cells. 


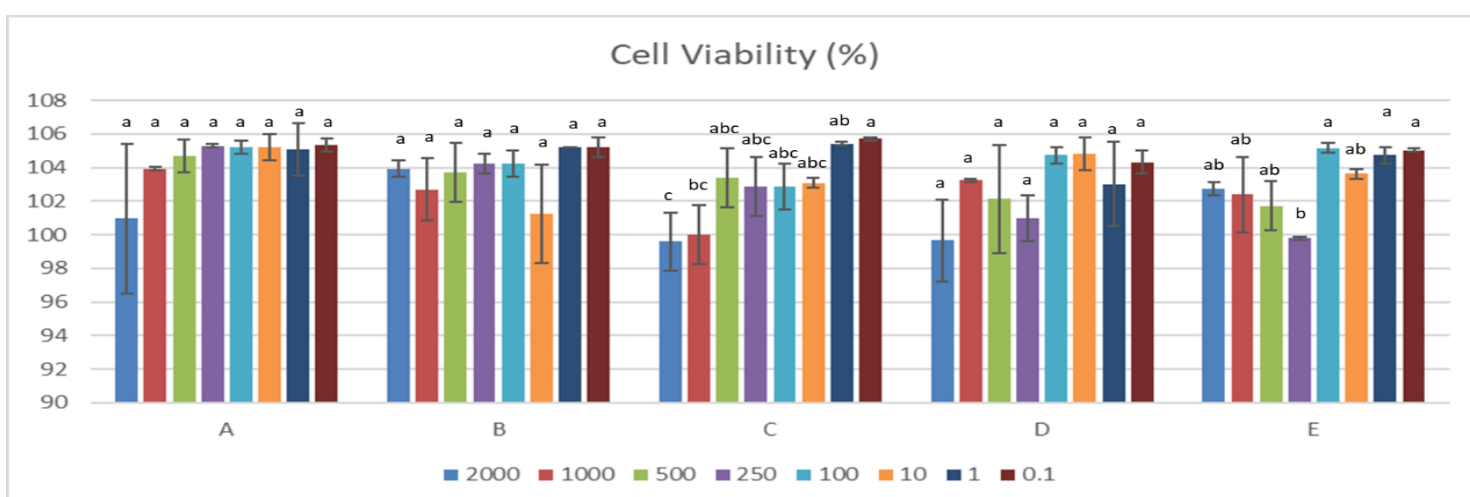

Figure 3. The percentage of cell viability after incubated with different compositions and concentrations of the scaffold as analyzed by One-way ANOVA followed by Tukey post hoc test. Different letters indicate significant differences $(\mathrm{p}<0.05)$. The graph is provided as mean $+\mathrm{SD}(\mathrm{n}=2)$.

In the results of the study, it can be seen that Table 1 at a concentration of $2000 \mathrm{mg} / \mathrm{ml}$ does not have a toxic effect on all samples. This shows that the five samples of chitosan/gelatin/chondroitin sulfate scaffold are not toxic, where all samples have a value of more than $70 \%$ (Nurfuadi, 2019).

Table 1. The viability of Hepatocellular Carcinoma (Huh7it/human hepatocyte It) cells (\%) after 48-hours incubation with different compositions and concentrations of the scaffold.

\begin{tabular}{ccccccccccc}
\hline Conc & \multicolumn{2}{c}{ KG (A) } & \multicolumn{2}{c}{ KGK (B) } & \multicolumn{2}{c}{ KGK (C) } & \multicolumn{2}{c}{ KGK (D) } & \multicolumn{2}{c}{ KGK (E) } \\
\cline { 2 - 11 }$(\mu \mathrm{g} / \mathrm{mL})$ & \%viability & SD & \%viability & SD & \%viability & SD & \%viability & SD & \%viability & SD \\
\hline 2000 & 100.96 & 4.47 & 103.92 & 0.49 & 99.59 & 1.75 & 99.66 & 2.43 & 102.75 & 0.39 \\
1000 & 103.92 & 0.1 & 102.68 & 1.85 & 100 & 1.75 & 103.23 & 0.1 & 102.41 & 0.21 \\
500 & 104.68 & 0.97 & 103.71 & 1.75 & 103.37 & 2.04 & 102.13 & 0.15 & 101.72 & 1.46 \\
250 & 105.3 & 0.1 & 104.26 & 0.58 & 102.89 & 1.75 & 100.96 & 1.36 & 99.79 & 0.1 \\
100 & 105.23 & 0.39 & 104.26 & 0.78 & 102.89 & 1.36 & 104.75 & 0.49 & 105.16 & 0.29 \\
10 & 105.23 & 0.78 & 101.24 & 2.92 & 103.09 & 0.29 & 104.81 & 0.97 & 103.65 & 0.29 \\
1 & 105.09 & 1.56 & 105.23 & 0 & 105.43 & 0.1 & 103.03 & 2.53 & 104.75 & 0.49 \\
0.1 & 105.36 & 0.39 & 105.23 & 0.58 & 105.71 & 0.1 & 104.33 & 0.68 & 105.02 & 0.1 \\
\hline
\end{tabular}

Table 1 exhibits the percentage of cell viability after 48-hour incubation with different compositions and concentrations of the scaffold. In composition $\mathrm{A}$, the highest cell viability was $105.36 \%$, in the cells incubated with $0.1 \mathrm{mg} / \mathrm{ml}$ of scaffold. Composition B shows 1 and $0.1 \mathrm{mg} / \mathrm{ml}$ scaffold resulted in the highest cell viability $105.23 \%$. The highest cell viability in composition $\mathrm{C}$ was observed in the cells incubated with $0.1 \mathrm{mg} / \mathrm{ml}$ scaffold. In composition $\mathrm{D}, 10 \mathrm{mg} / \mathrm{ml}$ scaffold gives the highest cell viability (104.81\%). Composition E shows the highest cell viability at $105.16 \%$ in the cells incubated with $100 \mathrm{mg} / \mathrm{ml}$.

As described above, even though there is no difference observed in cell viability after incubated with different concentrations and compositions of the scaffold, it seems that the highest cell viability comes from those incubated with under $10 \mathrm{mg} / \mathrm{ml}$ scaffold. From that perspective, it can be suggested that the lower the concentration the higher the cell viability. Nonetheless, since the cell viability from all the compositions and concentration regimes shows above the threshold $(70 \%)$ as defined by Nurfuadi (2019), the concentration of scaffold up to $2000 \mathrm{mg} / \mathrm{ml}$ using the composition regimes used in this study will not result in cytotoxicity.

A recent study conducted by Pratiwi (2020) reported that commercial scaffold composed of chitosan-chondroitin sulfate- 
gelatin does not toxic to Baby Hamster Kidney 21 (BHK-21) cells with the best composition at 35:45:20 (chitosan : chondroitin sulfate : gelatin). Meanwhile, the present study has shown that different compositions and concentrations of scaffold originated from waste-based resources do not affect the viability of Hepatocellular Carcinoma (Huh7it/ human hepatocyte It) cells, as shown by the high viability of cells incubated with the scaffold up to $2000 \mathrm{mg} / \mathrm{ml}$. This suggests that the scaffold composites originated from waste are reasonably safe to use at least in an in vitro environment.

\section{CONCLUSION}

It is concluded that waste-based chitosan, gelatin, and chondroitin sulfate as composites of scaffold is not toxic for Hepatocellular Carcinoma cells, in vitro. It has been proven that at least up to 2000 $\mathrm{ug} / \mathrm{ml}$ of scaffold used in this study shows no toxicity against the cells. Considering its non-toxicity, therefore, the waste-based scaffold is safe to use at least for in vitro research against human hepatocyte cells. However, further studies are also required to investigate whether or not the wastebased scaffold is also safe in vivo.

\section{ACKNOWLEDGMENT}

Researchers would like to thank the two supervisors and the NPRMD Tropical Disease Diagnostic Center (TDC), Airlangga University.

\section{REFERENCES}

Cahyani, S.L., 2019. Glutaraldehyde cytotoxicity test on chitosan gelatin scaffold against the viability of BHK (Baby Hamster Kidney)-21 fibroblas cells by MTT test. Thesis. Faculty of Pharmacy. Airlangga University. p. 57.

Duconseille, A., Astruc, T., Quintana, N., Meersman, F. and SanteLhoutellier, V., 2015. Gelatin structure and composition linked to hard capsule dissolution: A review. Food Hydrocolloids, 43, p.363. http://doi.org/10.1016/j.foodhyd.2 014.06 .006

Escobar-Sierra, D.M., Martins-Martins, J. and Ossa-Orozco, C.P., 2015. Chitosan/hydroxyapatite scaffolds for tissue engineering manufacturing method effect comparison. Revista Facultad de Ingeniería, 75, p.26. http://doi.org/ 10.17533/udea.redin.n75a04

Gunatillake, P., Mayadunne, R. and Adhikari, R., 2006. Recent developments in biodegradable synthetic polymers. Biotechnology Annual Review, 12, pp.301-347. http://doi.org/10.1016/S1387-265 6(06) 12009-8

Hartatik, Y.D., Nuriyah, L. anD Iswarin, 2014. Effect of chitosan composition on mechanical and biodegradable properties of bioplastic. Essay. Brawijaya University Repository. p.1. https://media.neliti.com/medi a/publications/159022-ID-pengaru h-komposisi-kitosan-terhadap-sifa.p df

Juliasti, R., Legowo, A.M. and Pramono, Y.B., 2014. Pengaruh Konsentrasi Perendaman Asam Klorida pada Limbah Tulang Kaki Kambing Terhadap Kekuatan Gel, Viskositas, Warna dan Kejernihan, Kadar Abu dan Kadar Protein Gelatin. Jurnal Teknologi Hasil Pertanian, 7(1), pp.32-38. https://doi.org/10.20961 /jthp.v0i0.12914

Kartikasari, N., Yuliati, A. and Kriswandini, $\quad$ I.L., 2016. Compressive strength and porosity tests on bovine hydroxyapatitegelatin-chitosan scaffolds. Dental journal, 49(3), pp.153-157. http://d oi.org/10.20473/j.djmkg.v49.i3.p1 53-157

Kavya, K.C., Dixit, R., Jayakumar, R., Nair, S.V. and Chennazhi, K.P., 2012. Synthesis and characterization of chitosan/chondroitin sulfate/Nano$\mathrm{SiO}_{2}$ composite scaffold for bone tissue engineering. Journal of biomedical nanotechnology, 8(1), 
p.149. https://doi.org/10.1166/jbn. 2012.1363

Levengood, S.K.L. and Zhang, M., 2014. Chitosan-based scaffolds for bone tissue engineering. Journal og materials chemistry $B, 21$, pp.31613184. http://doi.org/10.1039/c4tb $00027 \mathrm{~g}$

Neves, M.I., Araujo, M., Moroni, L., da Silva, R.M.P. and Barrias, C.C., 2020. Glycosaminoglycan-inspired biomaterials for the development of bioactive hydrogel networks. Molecules, 25(4), p.26. http://doi.or $\mathrm{g} / 10.3390 /$ molecules 25040978

Nurfuadi, A.R., 2019. Sintesis dan Karakterisasi Komposit Hidroksiapatit/Kolagen/Kitosan

Sebagai Kandidat Bone Scaffold (Doctoral dissertation, Universitas Airlangga).

O'Brein, F.J., 2011. Biomaterials \& scaffolds for tissue engineering. Materials today, 14(3), pp.88-95. http://doi.org/10.1016/s1369-702 1(11)70058-x

Peng, L., Cheng, X.R., Wang, J.W., Xu, D.X. and Wang, G., 2006. Preparation and evaluation of porous chitosan/collagen scaffolds for periodontal tissue engineering. Journal of Bioactive and Compatible Polymers. 21(3), p.207. http://doi.o $\mathrm{rg} / 10.1177 / 0883911506065100$

Pratiwi, Y.N., 2020. Cytotoxicity test of scaffold chitosan, gelatin, chondroitin sulfate by using BHK-21, in Vitro. Essay. p. 9.

Puspitaningrum, Y., 2015. Detection of cattle gelatin DNA and swine gelatin in vitamin $C$ gummy simulation using real time PCR for halal analysis. Thesis. p.7.

Siagan, C. 2014. Effects of Glucosaminechondroitin sulfate combination, glucosamine-chondroitin sulfatemethylsulfonymethane combination, and placebo on kell-joint osteoarthritis patients, degrees of Kellgren, Lawrence I and II. Thesis. p.10.
Singh, J.A., Noorbaloochi, S., MacDonald, R. and Maxwell, L.J., 2015. Chondroitin for oteoarthritis. Cochrane Database of Systematic Reviews, p.4. http://doi.org/10.100 2/14651858.CD005614.pub2

Venkatesan, J., Kim, S.K. and Wong, T.W., 2015. Chitosan and its application as tissue engineering scaffolds. Nanotechnology aplication for tissue engineering. William Andrew Publishing, pp.133-147. http://dx.d oi.org/10.1016/B978-0-323-32889$0.00009-1$

Wijayanti, T.R., 2016. The effect of chondroitin sulfate composition variations on the characteristics of chitosan-chondroitin sulfate/ hydroxyapatite scaffold composites as bone graft candidates. Essay, pp.2426. 